Gerontology 1978;24:I-VI

\title{
Contents Vol. 24, 1978
}

\section{No. 1}

Experimental Section

Gordon, H.A.; Rovin, S., and Bruckner, G.: Blood Flow, Collagen Components of Oral Tissue and Salivary Kallikrein in Young to Senescent, Germfree and Conventional Rats. A Study on the Etiologic Factors of Periodontal Disease 1 Zs.-Nagy, I.; Zs.-Nagy, V.; Pieri, C; Giuli, C, and Del Moro, M.: In vivo Stimulation of Nerve Cells by Phytohemagglutinin. I. Alterations of Some Cytological Aging Parameters in Rat Brain Cells 12 Hunziker, O.; Abdel'Al, S.; Frey, H.; Veteau, M.-J., and Meier-Ruge, W.: Quantitative Studies in the Cerebral Cortex of Aging Humans 27

Eichholz, R.L. and Buetow, D.E.: Total Free Amino Acid Levels in Adult and Senescent Rat Liver 32

Clinical Section

Füsgen, I. and Summa, J.D.: How Much Sense Is There in an Attempt to Resuscitate an Aged Person? 37

Rosin, A.J.: Treatment of Dyskinetic and Choreatic Movement Disorders in Adults . . Honoré, L.H.: Ageing Changes in the Human Testis: a Light-Microscopic Study .... Critical Review

Bassey, E.J.: Age, Inactivity and Some Physiological Responses to Exercise $\quad 66$ No. 2

Experimental Section

Frolkis, V. V. and Valueva, G. V.: Metabolism of Thyroid Hormones during Aging ... 81 McNamara, M.C.; Miller, A.T. jr.; Shen, A.L., and Wood, J.J.: Restitution of ATP and Creatine Phosphate after Experimental Depletion in Young, Adult, and Old Rats . 95 Massie, H.R.; Baird, M.B., and Williams, T.R.: Increased Longevity of Drosophila melanogaster with Diiodomethane 104 Contents

IV

Clinical Section

Resnitzky, P.; Touma, M., and Danon, D.: Neutrophilic Turnover Rate in Human Age Groups Evaluated by Serum Lysozyme Activity Ill

Nayal, A.S.; MacLennan, W.J.; Hamilton, J.C.; Rose, P., and Kong, M,: 25-Hydro xyVitamin D, Diet and Sunlight Exposure in Patients Admitted to a Geriatric Unit . 117

Review

Burch, P.R.J.: Coronary Heart Disease: Risk Factors and Ageing 123

No. 3

Experimental Section

Brooks, C. and Simons, E.R..- Effect of Age on Collagen Fibril Formation 
Gaubatz, J.W. and Gutter, R.G.: Age-Related Differences in the Number of Ribosomal RNA Genes of Mouse Tissues 179

Widdus, R.; Taylor, M.; Powers, L., and Danielli, J.F.: Characteristics of the 'Life Spanning' Phenomenon in Amoeba proteus. Independent Nuclear and Cytoplasmic Ability to Impose Finite 'Life Span' 208

Sperling, G.A.; Loosli, J.K.; Lupien, P., and McCay, CM. †: Effect of Sulfamerazine and Exercise on Life Span of Rats and Hamsters 220

Clinical Section

Atkinson, L.; Gibson, I., and Andrews, J.: An Investigation into the Abñity of Elderly Patients Continuing to Take Prescribed Drugs after Discharge from Hospital and Recommendations Concerning Improving the Situation 225

No. 4

Experimental Section

Poitrenaud, J.; Hazemann, P., and Lille, F.: Spontaneous Variations in Level of Arousal among Aged Individuals. Correlations with Functional Abilities and Mental Per formances 241

Bouissou, H; Julian, M., and Pieraggi, M.T.: Aortic Lathyrism and Atheroma in the Rat by Prolonged Hyperlipidic Diet 250

Fudenberg, H.H.; Schuman, S.H.; Goust, J.M., and Jorgenson, R.: T Cells, Precocious Aging, and Familial Neoplasia 266

Ordy, J.M.; Brizzee, K.R.; Kaack, B., and Hansche, J.: Age Differences in Short-Term Memory and Cell Loss in the Cortex of the Rat 276

Medvedev, Zh.A.; Medvedeva, M.N., and Robson, L.: Tissue Specificity and Age

Changes of the Pattern of the HI Group of Histones in Chromatin from Mouse

Tissues $\quad 286$

Contents

$\mathrm{V}$

Clinical Section

McKechnie, A.A.; Foster, E.M.; Bergmann, K., and Kay, D.W.K.: Psychiatric Illness in the Elderly. A Comparison of GP Records and Survey Findings 293

Neubauer, B. and Christensen, N.J.: The Decrease in Noradrenaline Concentration in the Posterior Tibial Artery with Age 299

Lloyd-Evans, S.; Brocklehurst, J.C., and Palmer, M.K.: Assessment of Drug Therapy in Chronic Brain Failure 304

No. 5

Experimental Section

Wiernsperger, N.; Danzeisen, M., and Meier-Ruge, W.: Effect of Carotid Ligation on Cerebral Tissue Oxygenation in Aging Rat 321

Hill, B.T. and Whelan, R.D.H.: Studies on the Degradation of Ageing Chromatin DNA by Nuclear and Cytoplasmic Factors and Deoxyribonucleases $\quad 326$

Ruiz-Torres, A.. Cross-Linking of Collagen Depending on Age 337

Haseeb, M.A. and Patnaik, B.K.: Age-Related Changes in Collagenous and Noncollagenous Proteins of Skeletal Muscle of a Short-Lived Species of Reptile 343 Wilson, P.D.: Differential Enzyme Distribution in Lobules of Livers from Young and Old Mice and Rats 348

Debate 
Tas, S.: Involvement of Disulfide Bonds in the Condensed Structure of Facultative Heterochromatin and Implications on Cellular Differentiation and Aging 358 Poplin, L. and DeLong, R.: Accelerated Aging due to Enzymatic Racemization .... 365 Clinical Section

Brun, A.; Gustafson, L., and Mitelman, F.: Normal Chromosome Banding Pattern in Alzheimer's Disease 369

Caldwell, J.; Smith, R.L., and Davies, S.A.: Drug Metabolism in a Case of Progeria . . 373 Palmblad, J. and Haak, A.: Ageing Does Not Change Blood Granulocyte Bactericidal Capacity and Levels of Complement Factors 3 and $4 \quad 381$

Critical Review

Sanford, A.J.: The Elderly and the Control of Simple Behaviour by Probabilistic Information 386

No. 6

Experimental Section

Hermelin, B. and Picard, J.: Lysosomal N-Acetyl-/3-hexosaminidase and B-Glucuronidase Activities from Arterial Wall. Variations with Aging 405

Contents

VI

Holliday, R. and Stevens, A.: The Effect of an Amino Acid Analogue, p-Fluorophenylalanine, on Longevity of Mice 417

Wilson, D.L.; Hall, M.E., and Stone, G.C.: Test of Some Aging Hypotheses Using

Two-Dimensional Protein Mapping 426

Hsu, H.K. and Peng, M.T.: Hypothalamic Neuron Number of Old Female Rats 434

Calderon, L.; Ryan, N., and Kovacs, K.: Human Pituitary Growth Hormone Cells on

Old Age $\quad 441$

Debate

Calow, P.: Bidder's Hypothesis Revisited. Solution to Some Key Problems Associated with General Molecular Theory of Ageing 448

Clinical Section

Chakravorty, N.K.: Some Unusual Features of Paget's Disease of Bone 459

Dubin, B.; MacLennan, W.J., and Hamilton, J.C.: Adrenal Function and Ascorbic Acid

Concentrations in Elderly Woman 473

Recent Articles in Experimental Ageing Research 156,235,312

Book Reviews 78, 160, 239, 318, 398, 477

Varia 240,404

Author Index 480

Subject Index 481

Supplement 1

Workshop on Advances in Experimental Pharmacology of Hydergine, Basel, December 2-3, 1976 